\title{
Amadeus
}

International Multidisciplinary Journal IISSN 2525-3281

DOI: 10.14295/aimj.v4i7.91

\section{Benzodiazepines use in elderly patients attended at a Public Pharmacy in Pernambuco Brazil}

Eliane da Silva Freitas Joaquim Alves Diniz ${ }^{\text {, }}$ Natália Rodrigues Alves ${ }^{I I}$, Pedro Ivo Palacio Leite , Modesto Leite Rolim Neto', Poliana Moreira Medeiros de Carvalho $^{I}$

\begin{abstract}
The elderly people are the group that most use psychotropic drugs, due to psychiatric comorbidity and somatic conditions. In Brazil some benzodiazepines are part of the National List of Essential Medicines (RENAME) being distributed free of charge, facilitating the population access, which can lead to irrational use. Methods: Cross-sectional, descriptive research through a qualitative and quantitative study of benzodiazepine use in patients attended at the Cedro Basic Pharmacy in the city of Cedro-PE. The data collection was done with the application of a semi-structured questionnaire. The pattern of benzodiazepine use has been described through patient-reported symptomatology, therapeutic adherence, medical specialty, dose increase without medical consultation, and adverse effects reported during the drug use. Results: There was a predominance of females $(58.33 \%)$. The most commonly used benzodiazepine was diazepam $(66.67 \%)$. The purchase of benzodiazepine without a prescription was reported by $16.67 \%$ of the elderly interviewed and an increase in the drug dose without doctor consulting by $25 \%$ of the interviewees. Final considerations: The prescription of these drugs for the elderly, as well as the chronic use, should consider the physiological changes caused by aging and the adverse effects of these drugs in order to guarantee a safe treatment.
\end{abstract}

Keywords : Aged; Psychotropic drugs; Drug utilization.

\footnotetext{
I Juazeiro do Norte Medical School (Estácio/FMJ), Juazeiro do Norte, Ceará, Brazil. orresponding author: modestorolim@yahoo.com.br

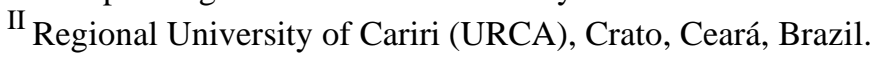




\section{Uso de benzodiazepínicos em idosos atendidos em Farmácia Pública de Pernambuco, Brasil}

\begin{abstract}
Resumo: Os idosos são o grupo que mais faz uso de psicofármacos, em decorrência de comorbidade psiquiátrica e da utilização em condições somáticas. No Brasil alguns benzodiazepínicos fazem parte da Relação Nacional de medicamentos Essenciais (RENAME) sendo distribuídos de forma gratuita facilitando o acesso da população o que pode acarretar em uso irracional. Metodologia: Pesquisa transversal, descritiva, através de um estudo qualitativo e quantitativo do consumo de benzodiazepínicos realizado em pacientes atendidos na Farmácia Básica de Cedro na cidade de Cedro-PE. A coleta de dados foi feita com a aplicação de um questionário semiestruturado. O padrão de uso dos benzodiazepínicos foi descrito através da sintomatologia referida pelo paciente, adesão terapêutica, especialidade médica, do aumento da dose sem consulta médica e efeitos adversos relatados durante o uso do medicamento. Resultados: Houve predominância do sexo feminino (58,33\%). O benzodiazepínico mais utilizado foi o diazepam $(66,67 \%)$. Foi relatada a compra de benzodiazepínico sem prescrição médica por $16,67 \%$ dos idosos entrevistados e aumento da dose do medicamento sem consultar o médico por 25\% dos entrevistados. Considerações Finais: A prescrição desses fármacos para idosos, assim como o uso crônico, devem considerar as alterações fisiológicas causadas pelo envelhecimento e os efeitos adversos desses medicamentos para que se possa garantir um tratamento seguro.
\end{abstract}

Palavras-Chave: Idosos; Psicotrópicos; Uso de Medicamentos.

\section{Introduction}

In the developing countries a fast and intense demographic and epidemiological change occurred, causing numerous difficulties of resolutions in face of the new demands of the growing age group: the elderly. Aging causes an increase in the number of chronic diseases and, consequently, in the use of drugs as an attempt to control these diseases and maintain the quality and quantity of years lived ${ }^{1,2,3}$.

Aging encompasses many diseases that require treatment with the use of psychoactive drugs. Older people are more susceptible to the use of these drugs but feel unsafe with clinically questionable indications for taking them, such as non-specific emotional distress or chronic insomnia ${ }^{4,5}$.

Prescription of psychoactive drugs in the elderly population is a common clinical practice. The elderly stands out as the age group that makes the most use of psychotropic drugs, due to the frequent presence of psychiatric comorbidity and the use of these drugs to alleviate somatic conditions ${ }^{6,7,8}$. 
In this situational context, benzodiazepines (BZDs), due to their efficacy and rapid onset of action, are widely used in clinical practice, constituting the largest group of prescribed psychotropic medications ${ }^{9,10}$.

In this sense, over the years, with the diffusion of consumption of BZDs, new problems were highlighted, most of them due to the inappropriate use of these drugs. Its abusive use has been the object of growing interest in health. In this context, the pharmaceutical-patient relationship is essential and pharmacists should be involved in documenting the history of medication. Pharmaceutical care should focus on the patient during the therapeutic intervention in order to promote the rational use of drugs ${ }^{11,12,13}$.

Thus, the rational use of medications is a paramount importance to avoid adverse effects that may compromise the health of the elderly. In order to do so, the improvement of the prescription, dispensation and use of drugs should be a priority in elderly care programs. The characterization of the profile of use can contribute to the creation of strategies to improve its prescription at national level ${ }^{14,15,16}$.

Due to the predominance of BZDs use among the elderly and the imminent risk of abuse of these drugs, this study intends to understand the circumstances that favor the irrational use of these drugs in the elderly population in the city of Cedro-PE.

In this context, the guiding question of this study was based on the acronym PICo, where P: Elderly (60 years old or older - National Policy of the Elderly (PNI), Law No. 842, January 4, 1994); I: Benzodiazepine and Co: Inappropriate use, time and indication. Are the elderly receiving benzodiazepines inadequately (in relation to dose and time of treatment)?

In Brazil, some BZDs are part of the National Relation of Essential Medicines (RENAME) and are distributed free of charge by the Sistema Único de Saúde (SUS), without adequate monitoring measures, which results in easy access and promotion of irrational use. The objective of this study was to characterize the consumption of benzodiazepines in a public pharmacy in the interior of Pernambuco from the analysis of medication use by their patients. 


\section{Methods}

Descriptive, cross-sectional study through a qualitative and quantitative study of benzodiazepine use in patients attended at the Cedro Basic Pharmacy in the city of CedroPE, in the public health network.

The research was carried out in the Basic Pharmacy of Cedro, located in the city of Cedro-PE, where the dispensation of basic and secondary care medicines is carried out by the public health network.

The choice of the public network was due to the fact that the medicines are distributed free of charge which facilitates the population access.

The research was carried out from March 1st to 31th, 2018. The data collection was done with the application of a semi-structured questionnaire with open and closed questions easily understandable for the patients. The questionnaire aimed to relate consumption habits, knowledge about adverse effects, regarding prescribed treatment and even polymedication and thus contribute to the achievement of the objectives of this work.

The questionnaire was adequate the needs of this study from the questionnaire found in the literature ${ }^{17}$.

The population selected for the data collection had its composition based on the elderly patients who have a registry in the Basic Pharmacy of Cedro and who frequently seek medicines in the unit with a prescription.

Was made of elderly patients enrolled using benzodiazepines was performed, and a total of 50 BZD users were obtained. Of these, 24 met the inclusion criteria and were selected to respond to the questionnaire.

The sample was the intentional type in which the sample calculation was based on the time of the research that lasted one month.

Patients were approached when they went to the pharmacy to get their medication. Patients who agreed to respond to the questionnaire signed the Informed Consent Term (TCLE).

The questionnaire was applied in a reserved room and after the application of the questionnaire the patients were advised about the risks of treatment with BZDs.

The characterization of the sample included the analysis of the following variables: sex, age, chronic diseases and quantity of medicines used. The standard of use of BZDs was described through patient-reported symptomatology, therapeutic adherence, medical 
specialty, dose increase without medical consultation and adverse effects reported during the use of the drug.

Elderly patients who were attended at the Basic Pharmacy of Cedro between March 01st and 31th, 2018, who had prescribed in their prescription benzodiazepine class drugs and were randomly chosen.

Patients who do not receive their medication personally. Patients who are not in possession of their mental faculties.

It is important to highlight that the research was approved by the Research Ethics Committee-CEP of the Faculdade de Juazeiro do Norte-FJN under number 2.610.143. The descriptive analysis was performed as basis.

Risk of embarrassment and exposure of the patients included in the study, but that will be minimal by the researcher's confidentiality, anonymity of the patients, even in the presentation of the results, because the names of the participants were not disclosed and the questionnaire was applied in a reserved room (where only the researcher and patient). The benefit will be attributed to improving the understanding of the proposed treatment, which will lead to better treatment efficacy and safety.

\section{Results}

A total of 24 benzodiazepine patients were interviewed, of whom $14(58.33 \%)$ were women and $10(41.67 \%)$ were men. The social and clinical data of these patients are demonstrated in table 1.

Table 1 - Distribution of the sample of patients, according to sociodemographic and clinical data.

\begin{tabular}{llll}
\hline & & $\mathbf{n}$ & $\%$ \\
\hline Gender & Female & 14 & 58,33 \\
& Mle & 10 & 41,67 \\
\hline Age & 60 to 70 years & 07 & 29,17 \\
& 71 to 80 years & 07 & 29,17 \\
& 81 to 90 years & 10 & 41,66 \\
\hline Symptomatology & Insomnia & 09 & 37,50 \\
& Depression & 06 & 25 \\
& Anxiety & 04 & 16,66 \\
& Pain & 02 & 8,33 \\
& Sadness & 01 & 4,17 \\
& Preocupation & 01 & 4,17
\end{tabular}




\begin{tabular}{llll} 
& Agitation & 01 & 4,17 \\
\hline Benzodiazepine & Diazepan & 16 & 66,67 \\
used & Clonazepan & 08 & 33,33 \\
\hline Understands the & Yes & 05 & 20,83 \\
proposed treatment & No & 19 & 79,17 \\
\hline Have Chronic & Yes & 21 & 87,5 \\
Disease Not & No & 03 & 12,5 \\
Transmissible & & & \\
(DCNT) & & & 75 \\
\hline Practice & Yes & 18 & 25 \\
Polypharmacy & No & 06 & \\
\hline
\end{tabular}

*N: 24 Patients (total of patients).

Source: original by the author.

Although non-prescription drug sales were prohibited, a total of $29.17 \%$ (7) of the respondents reported that they had tried to buy this class of medication without prescription, and $4(16.67 \%)$ reported that they were able to purchase, as shown in table 2.

Table 2 - Responses of the characterization of benzodiazepine consumption of the questionnaire.

\begin{tabular}{|c|c|c|c|}
\hline & & $\mathbf{n}$ & $\%$ \\
\hline $\begin{array}{l}\text { How long has the } \\
\text { doctor indicated } \\
\text { the use of this } \\
\text { medicine (s)? }\end{array}$ & $\begin{array}{l}\text { Less than } 2 \text { weeks } \\
3 \text { to } 4 \text { weeks } \\
5 \text { to } 6 \text { weeks } \\
6 \text { to } 8 \text { weeks } \\
\text { Until remission of } \\
\text { symptoms } \\
\text { Undetermined }\end{array}$ & $\begin{array}{l}0 \\
0 \\
0 \\
0 \\
2 \\
22\end{array}$ & $\begin{array}{c}0 \\
0 \\
0 \\
0 \\
8,33 \\
91,67\end{array}$ \\
\hline $\begin{array}{l}\text { Do you use the } \\
\text { medication (s) } \\
\text { every day? }\end{array}$ & $\begin{array}{l}\text { Yes } \\
\text { No }\end{array}$ & $\begin{array}{l}21 \\
03\end{array}$ & $\begin{array}{l}87,5 \\
12,5\end{array}$ \\
\hline $\begin{array}{l}\text { Have you ever } \\
\text { tried to buy this } \\
\text { drug (s) without a } \\
\text { prescription? }\end{array}$ & $\begin{array}{c}\text { Yes, I always do. } \\
\text { Yes, but I could } \\
\text { not. } \\
\text { No }\end{array}$ & $\begin{array}{l}4 \\
3 \\
17\end{array}$ & $\begin{array}{c}16,67 \\
12,5 \\
70,83\end{array}$ \\
\hline $\begin{array}{l}\text { Is the doctor who } \\
\text { prescribes the } \\
\text { drug (s) always } \\
\text { the same? }\end{array}$ & $\begin{array}{l}\text { Yes } \\
\text { No }\end{array}$ & $\begin{array}{l}10 \\
14\end{array}$ & $\begin{array}{l}41,67 \\
58,33\end{array}$ \\
\hline $\begin{array}{l}\text { When did the doctor } \\
\text { prescribe the } \\
\text { medication (s), did } \\
\text { he / she make any } \\
\text { special } \\
\text { recommendations } \\
\text { about the use? }\end{array}$ & $\begin{array}{l}\text { Yes } \\
\text { No }\end{array}$ & $\begin{array}{l}10 \\
14\end{array}$ & $\begin{array}{l}41,67 \\
58,33\end{array}$ \\
\hline \multicolumn{4}{|c|}{$\begin{array}{l}\text { *N: } 24 \text { Patients (total of patients). } \\
\text { Source: original by the author. }\end{array}$} \\
\hline 208 & $\begin{array}{l}\text { Am. In. Mult. J } \\
\text { Eletronic editio }\end{array}$ & $\begin{array}{l}\text { nber, } \\
\text { eusjol }\end{array}$ & br/amadeus \\
\hline
\end{tabular}


It was found that $12.5 \%$ (3) of the interviewees did not use the medication every day and when asked why they answered that they did not realized the need to do so.

Most physicians did not limit the time of time treatment with BZDs, a fact that can lead to long periods of use, generating tolerance and a consequent increase in the dose, making it difficult to abandon this medication and the remission of symptoms. Tolerance in some cases contributed to another problem: irrational use. A fact demonstrated in this study where one can observe the self-medication and increase of the drug dose without medical guidance, as shown in table 3.

Table 3 - Responses of the characterization of the benzodiazepine consumption of the questionnaire.

\begin{tabular}{llcc}
\hline & & $\mathbf{n}$ & $\mathbf{\%}$ \\
\hline $\begin{array}{l}\text { Have you ever felt that } \\
\text { the medication (s) lost } \\
\text { (lost) effect? }\end{array}$ & No & 09 & 37,5 \\
& & 15 & 62,5 \\
\hline $\begin{array}{l}\text { Have you already } \\
\begin{array}{l}\text { increased the dose of the } \\
\text { drug (s) without }\end{array}\end{array}$ & No & 06 & 25 \\
$\begin{array}{l}\text { consulting your doctor? } \\
\text { No }\end{array}$ & 18 & 75 \\
\hline
\end{tabular}

\begin{tabular}{|c|c|c|c|}
\hline $\begin{array}{l}\text { Have you used this } \\
\text { medication (s) without } \\
\text { your doctor's } \\
\text { prescription? }\end{array}$ & $\begin{array}{l}\text { Yes } \\
\text { No }\end{array}$ & $\begin{array}{l}04 \\
20\end{array}$ & $\begin{array}{l}16,67 \\
83,33\end{array}$ \\
\hline $\begin{array}{l}\text { Have you already } \\
\text { recommended your } \\
\text { medication (s) to } \\
\text { relatives or friends on } \\
\text { account of a good result } \\
\text { obtained? }\end{array}$ & $\begin{array}{l}\text { Yes } \\
\text { No }\end{array}$ & $\begin{array}{l}05 \\
19\end{array}$ & $\begin{array}{r}20,83 \\
79,17\end{array}$ \\
\hline $\begin{array}{l}\text { Do you know of any } \\
\text { risks regarding the use } \\
\text { of this medication (s)? }\end{array}$ & $\begin{array}{l}\text { Yes } \\
\text { No }\end{array}$ & $\begin{array}{l}07 \\
17\end{array}$ & $\begin{array}{l}29,17 \\
70,83\end{array}$ \\
\hline $\begin{array}{l}\text { After you started using } \\
\text { this medicine (s) did you } \\
\text { experience any adverse } \\
\text { effects? }\end{array}$ & $\begin{array}{l}\text { Yes } \\
\text { No }\end{array}$ & $\begin{array}{l}13 \\
11\end{array}$ & $\begin{array}{l}54,17 \\
45,83\end{array}$ \\
\hline
\end{tabular}

Table 4 shows the number of recommendations from physicians to patients regarding the use of benzodiazepines, a total of $33.33 \%$ (8) of the patients reported 
receiving information on three types of side effects, $4.17 \%$ (1) on two and $4.17 \%$ (1) on one. The recommendations made by the doctors most cited by the patients were: not to associate with alcohol 33.33\% (8) and somnolence 25\% (6). Among the less remembered, we highlight dependence of $16.67 \%$ (4), dizziness $12.5 \%$ (3), fall $8.34 \%$ (2), abstinence $8.34 \%$ (2) and tolerance $4.17 \%$ (1). It was also observed that $4.17 \%$ (1) of the patients cited recommendations that do not fit the literature (intake at night).

Table 4 - Medical specialties, recommendations on use and adverse effects found.

\begin{tabular}{|c|c|c|c|}
\hline & & $\mathbf{n}$ & $\%$ \\
\hline Medical & General Clinic & 20 & 83,33 \\
\hline \multirow[t]{3}{*}{ specialties } & Neurologist & 02 & 8,33 \\
\hline & Orthopedist & 01 & 4,17 \\
\hline & Cardiologist & 01 & 4,17 \\
\hline \multirow{4}{*}{$\begin{array}{l}\text { Recommendations } \\
\text { on use for each } \\
\text { patient }\end{array}$} & $\begin{array}{l}\text { Three } \\
\text { recommendations }\end{array}$ & 08 & 33,33 \\
\hline & $\begin{array}{l}\text { Two } \\
\text { recommendations }\end{array}$ & 01 & 4,17 \\
\hline & $\begin{array}{l}\text { One } \\
\text { recommendations }\end{array}$ & 01 & 4,17 \\
\hline & None & 14 & 58,33 \\
\hline \multirow{5}{*}{$\begin{array}{l}\text { Adverse Effects } \\
\text { Found by Patient }\end{array}$} & Three Adverse & 07 & 29,16 \\
\hline & Effects & & \\
\hline & $\begin{array}{l}\text { Two Adverse } \\
\text { Effects }\end{array}$ & 04 & 16,67 \\
\hline & One Adverse & 02 & 8,34 \\
\hline & $\begin{array}{l}\text { Effects } \\
\text { None }\end{array}$ & 11 & 45,83 \\
\hline
\end{tabular}

* N: 24 Patients (total of patients).

Source: original by the author.

A great part of the interviewees reported having adverse events, 54.17\% (13). The adverse events reported were: imbalance $45.83 \%$ (11), weakness $29.17 \%$ (7), sleep 25\% (6), loss of attention $20.83 \%$ (5) and urinary incontinence $8.34 \%$ (2).

\section{Discussion}

Women were the ones that used the most BZDs, about 58.33\%. This female prevalence obtained in this study coincides with other investigations performed with geriatric populations ${ }^{18,19,20}$. This predominance is due to the fact that women maintain greater care with their health, identify and report with more clarity and ease physical and 
psychological symptoms, and also because of the greater fragility that is attributed to them by society ${ }^{21}$.

Table 1 shows that a high number of elderly people with chronic noncommunicable diseases (CNCDs) corroborates other studies ${ }^{22,23}$. The aging process increases the number of people with CNCDs, who demand continuous care and where drugs play an important role, making them more susceptible to polypharmacy ${ }^{24}$. The practice of polypharmacy can also be verified in this study in table 1 where it is observed that $75 \%$ (18) of the patients practice it.

The main reasons that led patients, regardless of gender, to use benzodiazepines were insomnia, followed by depression and anxiety. Pain, agitation, worry and sadness were still found as reasons. In the other two studies, the first one shows that insomnia and anxiety were also the most frequent causes ${ }^{25}$ and the second one reported that the diagnosis of depression was the most recurrent ${ }^{26}$.

The most used benzodiazepine in this research was diazepam, which diverges from the results found in the literature in which there was a greater use of clonazepam ${ }^{27,28}$. The divergence between the data found in the literature and the data from this study regarding the most consumed BZDs may be a result of the prescribers' preference in choosing to prescribe diazepam.

There is a group of drugs known as Potentially Inappropriate Medications (MPI) that are at high risk for the development of Adverse Drug Reaction (ADR) and do not have sufficient evidence of its benefits. The risks added to its use may exceed beneficial therapeutic actions. Even with evidence associated with negative closures, they continue to be prescribed and used in the elderly ${ }^{29,30}$.

The main indication of the BZDs in this study was for insomnia, however the relevant literature states that prescriptions of all benzodiazepines should be avoided for the elderly to treat insomnia, agitation or delirium, considering that these drugs for the treatment of this clinical condition are MPI ${ }^{31}$. However, the MPI most consumed are the drugs for the central nervous system, especially benzodiazepines ${ }^{14}$.

In the national literature, 58 users and 232 non-users of benzodiazepine were evaluated, registering an association between the use of this psychotropic medication and excessive daytime sleepiness and postural instability ${ }^{32}$. This finding was corroborated in the study where the most frequent adverse effects were imbalance, weakness and sleep. 
The variety of subterfuges used to achieve benzodiazepine prescription shows that the connection is not established with the specialist or the health service, but with the medication itself ${ }^{33}$. This fact was also observed in this study in which the majority of the interviewees, $58.33 \%$ (14), obtained the prescription with different doctors and it was possible to observe that they only go to the doctor to get a new prescription of BZD, of patients contribute to the indiscriminate use and consequently to increase the risks of adverse effects triggered by the BZDs.

Treatment with BZDs for prolonged periods and the difficulty in adequate followup, together with the possibility of self-medication of patients, are considered as irrational practices. Its prolonged use can cause problems associated with discontinuation and symptoms of retraction and abuse. Many chronic users of BZDs obtain prescription with physicians, but are not informed about their risks ${ }^{16,34,35}$, which corroborates with the data obtained in this research in which one can verify the occurrence of self-medication, long periods of treatment and most respondents reported that they did not know the rich associated with the use of these drugs.

Among the reported symptoms, depression and anxiety would require psychiatric follow-up, which was not observed in this study, since none of the prescribing specialties was in the area of psychiatry, as shown in table 4. The literature shows that among users of these medications, only $3.2 \%$ had follow-up with a psychiatrist in the previous 12 months, while $94.5 \%$ consulted physicians in other specialties during the same period ${ }^{36}$.

Although the use of non-prescription psychotropic drugs is illegal in most countries, BZDs, because they have activity in the nervous system and can generate tolerance and physical and psychic dependence, are constantly used as drug abuse ${ }^{37}$. Tables 2 and 3 show the abusive use of these drugs; a total of $16.67 \%$ (4) of the patients reported that they had used BZD without the doctor's prescription and that they were able to buy this class of drug without prescription, $25 \%$ (6) already increased the dose without consulting the doctor and $20,83 \%$ (5) recommended these drugs to relatives or friends.

The continuity of the use of these drugs is going beyond a specific purpose without determined time. Its abusive use is reported in both developed and developing countries. The use without medical guidance or in amounts/periods greater than those recommended for treatment has increased in recent years, becoming a concern in the public health ${ }^{38,35,39}$.

The most frequent orientation of prescribers to users of BZDs in the literature found was not drinking, ${ }^{40}$ which corroborates with the data from this study in which the 
recommendation made by the doctors most cited by the patients was not to associate with alcohol. This fact demonstrates that prescribers attach greater importance to the pharmacological interaction between alcohol and BZDs than to other side effects such as dependence and tolerance, a fact that may contribute to the abusive use of these drugs.

Minimum effective doses as well as short periods of treatment, usually 2-3 weeks of treatment, should be indicated in order to reduce the dependence caused by BZDs, since no additional benefits are received when treatment is prolonged ${ }^{41}$. However, in this study, $22(91.67 \%)$ patients did not receive information regarding the time of treatment with BZD, which can generate tolerance and make it difficult to withdraw this medication.

In this context, the presence of the pharmacist and the provision of pharmaceutical care for the geriatric population is important to improve the patient's understanding of the proposed treatment and promote the rational use of these drugs, which may reduce the occurrence of adverse effects. However, pharmaceutical care is still in its principle.

\section{Conclusion}

BZDs are the most consumed psychotropic drugs in the world and are also the major cause of addiction, even so, its use among the elderly is high. Medical guidance on drug dependence was low, while use was high, suggesting that prescribers need to be more attentive to this undesirable effect during patient counseling.

The prescribing of BZDs for the elderly should consider the physiological changes caused by aging and the adverse effects of these drugs, so that it can be verified that the benefit of the use is greater than the risk, trying to avoid prescribing MPI in order to preserve the patient's health.

\section{References}

1. Cohen R, Paskulin LMG, Prieb, RGG. Prevalência de sintomas depressivos entre idosos em um serviço de emergência. Rev Bras Geriatr Gerontol 2015; 18(2): 307317.

2. Almeida NA DE, Reiners AAO, Azevedo RC DE S, Silva AMC DA, Cardoso IDC, Souza 1C DE. Prevalência e fatores associados à polifarmácia entre os idosos residentes na comunidade. Rev Bras Geriatr Geronto 2017; 20(1): 143-153. 
3. Muniz ECS, Goulart FC, Lazarini CA, Marin MJS. Análise do uso de medicamentos por idosos usuários de plano de saúde suplementar. Rev Bras Geriatr Geronto 2017; 20(3): 375-387.

4. Carvalho ILN, Lôbo APA, Aguiar CA DE A, Campos AR. A intoxicação por psicofármacos com motivação suicida: uma caracterização em idosos. Rev Bras Geriatr Geronto 2017; 20(1): 134-142.

5. Sgnaolin V, Engroff $\mathrm{P}$, Andrade CP, Loureiro F, Nogueira EL, Neto AC, et al. Patterns of chronic benzodiazepine use in the elderly. Arch Clin Psychiatry 2016; 43(4):79-82.

6. Gómez S, León T, Macuer M, Alves M, Ruiz S. Uso de benzodiazepinas en adultos mayores en América Latina. Rev Med Chile 2017; 145: 351-359.

7. Ricardo LIS, Gárciga FFH. Consumo de benzodiazepinas en pacientes geriátricos del Consultorio \# 12, Policlínico "Campo Florido". Revista Cubana de Farmacia 2010; 44(3): 346-353.

8. Secoli SR. Polifarmácia: interações e reações adversas no uso de medicamentos por idosos. Rev Bras Enferm 2010; 63(1): 136-40.

9. Danza A, Branco MR, Pampín ML, Agorio D, Caleri A, Patiño I, et al. Benzodiazepinas y fractura de cadera: estudio de casos y controles. Rev Méd Urug 2015; 31(2):120-127.

10. Fresán A, Minaya O, Cortés-lópez JL, Ugalde O. Características demográficas y clínicas associadas a la dependencia a benzodiacepinas en pacientes psiquiátricos. Salud Mental 2011; 34(2):103-109.

11. Firmino KF, Abreu MHNG, Perini E, Magalhães SMS. Fatores associados ao uso de benzodiazepínicos no serviço municipal de saúde da cidade de Coronel Fabriciano, Minas Gerais, Brasil. Cad Saúde Pública 2011; 27(6):1223-1232.

12. Gonçalves DP, Silva IV, Rangel LB, Rezende LC. Prescription of psychoactive drugs in patients attended by the SUS at Manhuaçu - MG (Brazil). Pharmacy Practice 2011; 9(4): 200-206.

13. Mota DM, Costa AA, Teixeira CS, Bastos AA, Dias MF. Uso abusivo de benzidamina no Brasil: uma abordagem em farmacovigilância. Ciência \& Saúde Coletiva 2010;15(3): 717-724.

14. Lutz BH, Miranda VIA, Bertoldi AD, Inadequação do uso de medicamentos entre idosos em Pelotas, RS. Rev Saúde Pública 2017; 51:52.

15. Lopes LM, Figueiredo TP DE, Costa SC, Reis AMM. Utilização de medicamentos potencialmente inapropriados por idosos em domicílio. Ciência \& Saúde Coletiva 2016; 21(11): 3429-3438.

16. Speranza N, Domínguez V, Pagano E, Artagaveytia P, Olmos I, Toledo M, et al. Consumo de benzodiazepinas en la población uruguaya: un posible problema de salud pública. Rev Méd Urug 2015; 31(2):112-119.

17. Soares C DE N, Soares MB DE M, Asbahr FR, Bernik MA. Perfil de uso e abuso de benzodiazepínicos em pacientes psiquiátricos e não-psiquiátricos. $J$ bras Psiquiatr 1991; 40(4): 191-8.

18. Gonçalves A, Ferreira M, Florentim R, Sousa A, Reis M, Cabral L. Consumo de benzodiazepinas no idoso deprimido. Revista Portuguesa de Enfermagem de Saúde Mental (Spe. 5) 2017; 107-111.

19. Telles Filho PCP, Chagas AR, Pinheiro MLP, Lima AMJ, Durão AMS. Utilização de benzodiazepínicos por idosos de uma estratégia de saúde da família: implicações para enfermagem. Esc Anna Nery 2011; 15 (3):581-586. 
20. Noia AS, Secoli SR, Duarte YA DE O, Lebrão ML, Lieber NSR. Fatores associados ao uso de psicotrópicos por idosos residentes no Município de São Paulo. Rev Esc Enferm USP 2012; 46(Esp):38-43.

21. Abi-ackel MM, Lima-Costa MF, Castro-Costa E, Filho AI DE L. Uso de psicofármacos entre idosos residentes em comunidade: prevalência e fatores associados. Rev Bras Epidemiol 2017; 20(1): 57-69.

22. Alvim MM, Cruz DT DA, Vieira M DE T, Bastos RR, Leite ICG. Prevalence of and factors associated with benzodiazepine use in community-resident elderly persons. Rev. Bras Geriatr Gerontol 2017; 20(4): 463-474.

23. Manso MEG, Biffi ECA, Gerardi TJ. Prescrição inadequada de medicamentos a idosos portadores de doenças crônicas em um plano de saúde no município de São Paulo, Brasil. Rev Bras Geriatr Gerontol 2015; 18(1):151-164.

24. Carvalho MFC, Romano-Lieber NS, Bergsten-Mendes G, SecolI SR, Ribeiro E, Lebrão ML et al. Polifarmácia entre idosos do Município de São Paulo - Estudo SABE. Rev Bras Epidemiol 2012; 15(4): 817-27.

25. García-Baztán A, Roqueta C, Martínez-Fernández MI, Colprim D, Puertas P, Miralles R. Prescripción de benzodiacepinas en el anciano en diferentes niveles asistenciales: características y factores relacionados. Rev Esp Geriatr Gerontol 2014; 49(1): 24-28.

26. Steinman MA, Low M, Balicer RD, Shadmi E. Epidemic Use of Benzodiazepines among Older Adults in Israel: Epidemiology and Leverage Points for Improvement. $J$ Gen Intern Med 2017; 32(8): 891-9.

27. Naloto DCC, Lopes FC, Barberato-Filho S, Lopes LC, Fiol F DE SD, Bergamaschi CC. Prescrição de benzodiazepínicos para adultos e idosos de um ambulatório de saúde mental. Ciência \& Saúde Coletiva 2016; 21(4):1267-1276.

28. Cunha CDA, Souza MCC DE, Cattanio GAA, Iahnn SR, Lima R DA C. Benzodiazepine use and associated factors in elderly in the city of Dourados, MS, Brazil. J Bras Psiquiatr 2015; 64(3): 207-12.

29. Andrade KVF DE, Filho CS, Junqueira LL. Prescrição de medicamentos potencialmente inapropriados para idosos: um estudo transversal em instituição psiquiátrica. J Bras Psiquiatr 2016; 65(2):149-54.

30. Salech F, Palma D, Garrido P. Epidemiología del uso de medicamentos en el adulto mayor. REV.MED CLIN CONDES 2016; 27(5): 660-670.

31. Oliveira MG, Amorim WW, Borja-Oliveira CR DE, Coqueiro HL, Gusmão LC, Passos LC. Consenso brasileiro de medicamentos potencialmente inapropriados para idosos. Geriatrics Gerontology and Aging 2016; 10(4): 1-14.

32. Martins APAF, Carvalho MR DE, Ribeiro LG, Santos TV, Ramos MTA, Galvão DO, et al. Uso de benzodiazepínicos por idosos: sonolência diurna excessiva, instabilidade postural e adequação da prescrição na Estratégia de Saúde da Família. Revista da Universidade Vale do Rio Verde 2015; 13(1): 462-472.

33. Alvarenga JM, Giacomin KC, Filho AI DE L, Uchoa E, Firmo JOA. Uso crônico de benzodiazepínicos entre idosos. Rev Saúde Pública 2014; 48(6): 866-872.

34. Olfson M, King M, Schoenbaum M. Benzodiazepine Use in the United States. JAMA Psychiatry 2015; 72(2): 136-142.

35. Souza ARL, Opaleye ES, Noto AR. Contextos e padrões do uso indevido de benzodiazepínicos entre mulheres. Ciência \& Saúde Coletiva 2013; 18(4):1131-1140.

36. Alvarenga JM, Filho AI DE L, Firmo JOA, Lima-Costa MF, Uchoa E. Prevalence and sociodemographic characteristics associated with benzodiazepines use among community dwelling older adults: The Bambuí Health and Aging Study (BHAS). Rev Bras Psiquiatr 2007; 30(1): 7-11. 
37. Coutinho D, Vieira DN, Teixeira HM. Condução sob influência de benzodiazepinas e antidepressivos: Prescrição Médica e Abuso. Acta Med Port 2011; 24(3): 431-438.

38. Lira AC, Lima JG DE, Barreto MNS DE C, Melo TMAG DE. Perfil de usuários de benzodiazepinicos no contexto da atenção primária à saúde. Rev APS 2014; 17(2): 223-228.

39. Firmino KF, Abreu MHNG, Perini E, Magalhães SMS. Utilização de benzodiazepínicos no Serviço Municipal de Saúde de Coronel Fabriciano, Minas Gerais. Ciência \& Saúde Coletiva 2012; 17(1):157-166.

40. Auchewskia L, Andreatinia R, Galdurózb JCF, Lacerda RB DE. Avaliação da orientação médica sobre os efeitos colaterais de benzodiazepínicos. VER BRAS Psiquiatr 2004; 26(1): 24-31.

41. Vantour AL, Arzuaga AA, Romero JB, Fontela NO. Uso y abuso de las benzodiazepinas. MEDISAN 2010;14(4): 555.

\section{How to cite this article (APA format):}

Freitas, Eliane da Silva; Diniz, Joaquim Alves; Alves, Natália Rodrigues; Leite, Pedro Ivo Palacio; Rolim Neto, Modesto Leite; Carvalho, Poliana Moreira Medeiros de. (2019). Benzodiazepines use in elderly patients attended at a Public Pharmacy in Pernambuco Brazil. Am. In. Mult. J., October a December. (7) 4, 203-216.

Received: $11 / 25 / 2019$

Accepted: 12/05/2019 